\title{
MAX Gene-Associated Protein
}

National Cancer Institute

\section{Source}

National Cancer Institute. MAX Gene-Associated Protein. NCI Thesaurus. Code C115318.

MAX gene-associated protein (3026 aa, $\sim 332 \mathrm{kDa}$ ) is encoded by the human MGA gene.

This protein plays a role in the in the modulation of MYC and MAX-dependent gene transcription. 